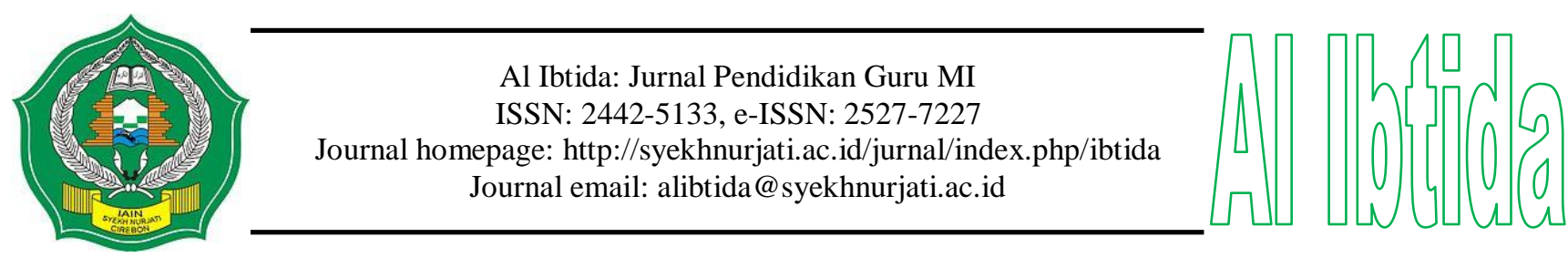

\title{
Pengaruh Metode Demonstrasi dengan Alat Peraga Jembatan Garis Bilangan Terhadap Hasil Belajar Matematika Materi Bilangan Bulat
}

\author{
Ahmad Arifuddin* \\ *Jurusan Pendidikan Guru Madrasah Ibtidaiyah, Fakultas Ilmu Tarbiyah dan Keguruan, \\ IAIN Syekh Nurjati Cirebon \\ Email: arief.udien4@gmail.com \\ Siti Rohmah Arrosyid** \\ **Jurusan Pendidikan Guru Madrasah Ibtidaiyah, Fakultas Ilmu Tarbiyah dan Keguruan, \\ IAIN Syekh Nurjati Cirebon \\ Email: sitirohmah671@gmail.com
}

Received 14 August 2017; Received in revised form: 16 October 2017; Accepted 18 October 2017

Publish Online: 27 October 2017

\begin{abstract}
Abstrak
Salah satu mata pelajaran yang sangat penting untuk diajarkan di sekolah dasar adalah Matematika. Akan tetapi, hingga saat ini guru matematika masih dihadapkan pada permasalahan bahwa matematika merupakan salah satu mata pelajaran yang dianggap sulit dan tidak disenangi oleh siswa, sehingga hasil belajar siswa masih rendah atau tidak memenuhi Kriteria Ketuntasan Minimal (KKM). Penelitian ini bertujuan untuk: (1) mengetahui proses pembelajaran Matematika materi bilangan bulat dengan metode demonstrasi menggunakan alat peraga jembatan garis bilangan, (2) mengetahui hasil belajar Matematika materi bilangan bulat setelah menggunakan metode demontrasi dengan alat peraga jembatan garis bilangan, dan (3) mengetahui pengaruh metode demonstrasi dengan alat peraga jembatan garis bilangan terhadap hasil belajar Matematika materi bilangan bulat siswa kelas IV SDN 2 Belawa Kabupaten Cirebon. Penelitian ini merupakan penelitian eksperimen dengan desain penelitian one group pretest postest design. Teknik pengumpulan data yang digunakan dalam penelitian ini adalah tes dan angket. Sementara itu, Data hasil penelitian dianalisis menggunakan analisis regresi. Hasil penelitian menunjukan bahwa terdapat pengaruh yang signifikan antara metode demonstrasi dengan alat peraga jembatan garis bilangan dengan hasil belajar matematika materi bilangan bulat siswa kelas IV SDN 2 Belawa Kabupaten Cirebon. Hal ini ditunjukkan dengan nilai uji determinasi sebesar 0,650 atau $65 \%$.
\end{abstract}

Kata kunci: demonstrasi, jembatan garis bilangan, hasil belajar bilangan bulat 


\begin{abstract}
One of the most important subjects to be taught in elementary school is Mathematics. However, until now the mathematics teacher is still faced with the problems that mathematics is one of the subjects that are considered difficult and not liked by the students. So that student learning outcomes is low or does not meet the minimum completeness criteria (KKM). This research aims to: (1) understand the process of learning mathematics in integer material with demonstration method using bridge props of number line, (2) determine the learning outcomes of mathematics in integer material after using demonstration method with bridge props of number line, and (3) the effect of demonstration method with bridge props number line to the learning outcomes of mathematics in integer material grade IV SDN 2 Belawa Cirebon. This research is an experimental research with research design one group pretest postest design. Data collection technique used is a test and questionnaire. Meanwhile, the data of the research were analyzed using regression analysis. The results of the research showed that a significant difference between the methods of demonstration with props bridge number line with the learning outcomes of fourth grade students of SDN 2 Belawa Cirebon. This is indicated by the test value determination equal to 0.650 or $65 \%$.
\end{abstract}

Keywords: demonstration, bridge number line, learning outcomes integer

\title{
PENDAHULUAN
}

Salah satu faktor utama dalam rangka meningkatkan mutu pendidikan adalah dengan meningkatkan mutu kegiatan belajar mengajar yang di dalamnya terdapat guru dan peserta didik yang memiliki perbedaan kemampuan, keterampilan, filsafat hidup, karakteristik dan sebagainya. Adanya perbedaan tersebut menjadikan pembelajaran sebagai proses pendidikan memerlukan model, metode, strategi dan alat peraga yang bermacam-macam sehingga peserta didik dapat menguasai materi dengan baik dan mendalam. Tidak jarang kita jumpai hasil belajar siswa belum dapat mencapai target yang telah ditentukan oleh sekolah dalam Kriteria Ketuntasan Minimal (KKM), termasuk pada mata pelajaran matematika.

Matematika sebagai mata pelajaran yang mampu membentuk pola pikir seseorang berpikir terstruktur dan logis perlu dipelajari sedini mungkin. Dengan belajar matematika, siswa diharapkan dapat menghubungkan dan memahami suatu hubungan antara konsep matematika yang satu dengan konsep matematika yang lain untuk memecahkan masalah dalam kehidupan sehari-hari. Akan tetapi permasalahannya adalah guru belum mampu menyampaikan materi matematika yang abstrak tersebut dengan baik, sehingga siswa merasa kesulitan dalam mempelajari materi matematika. Keabstrakan matematika tersebut menurut (Arifuddin, 2016) karena memang matematika berkaitan dengan simbol-simbol dan konsepkonsep, sehingga untuk mempelajarinya membutuhkan pemahaman dengan nalar yang tinggi. Oleh karena itu, untuk mengatasi kesulitan siswa dalam mempelajari materi matematika 
diperlukan sebuah metode dan alat peraga yang sesuai dengan karakteristik materi matematika tersebut.

Arsyad (2013: 9) mengatakan bahwa Alat peraga adalah media alat bantu pembelajaran dengan segala macam benda yang digunakan untuk memperagakan materi pelajaran. Sementara itu, Hamalik dalam (Maufur, 2016: 243) mengemukakan bahwa pemakaian media pembelajaran dalam proses belajar mengajar dapat membangkitkan keinginan dan minat yang baru, membangkitkan motivasi dan rangsangan kegiatan belajar bahkan membawa pengaruh psikologis terhadap siswa yang berpengaruh pula pada hasil belajarnya.

Berdasarkan teori Piaget, siswa Sekolah Dasar (SD/MI) termasuk dalam tahap operasional konkrit, artinya untuk memahami suatu konsep, siswa harus didekatkan dengan objek-objek nyata yang dapat diterima dalam kemampuan kognitif mereka. Oleh karena itu, kegiatan pembelajaran yang tepat adalah kegiatan pembelajaran yang berpusat pada siswa atau student centered. Pada kegiatan pembelajaran ini, aktivitas dan peran siswa lebih banyak daripada guru. Kegiatan siswa untuk terlibat langsung seperti melakukan pengamatan, eksperimen dan penemuan akan berdampak pada meningkatnya hasil belajar siswa, sedangkan guru berperan sebagai fasilitator dan motivator. Kegiatan belajar yang berpusat pada siswa akan memberikan manfaat diantaranya siswa akan tumbuh menjadi aktif, disiplin, cerdas, konsep-konsep yang diperolehnya akan tersimpan lama dalam memori otaknya.

Salah satu pokok bahasan pada mata pelajaran matematika kelas IV SD/MI yang selama ini dirasakan sulit dipelajari oleh siswa adalah bilangan bulat. Kesulitan ini karena memang materi bilangan bulat bersifat abstrak. Hal ini berdampak pada rendahnya hasil belajar siswa yang tidak mencapai nilai KKM lebih dari 50\%. Berdasarkan hasil observasi peneliti dengan Guru Kelas IV Ibu Neni Sumarni, S.Pd pada tanggal 26 Januari 2017 menerangkan bahwa khusus materi bilangan bulat siswa tidak mampu memahami apa yang disampaikan oleh guru. Ketidakmampuan ini selain bilangan bulat bersifat abstrak, guru belum mampu mengelola pembelajaran dengan baik. Guru belum tepat menggunakan metode dan alat peraga yang sesuai dengan karakteristik materi bilangan bulat.

Oleh karena itu, salah satu cara untuk meningkatkan hasil belajar siswa pada materi bilangan bulat adalah menggunakan metode demonstrasi dengan alat peraga jembatan garis bilangan. Metode demonstrasi adalah metode yang digunakan untuk memperlihatkan suatu proses atau cara kerja suatu benda yang berkenaan dengan bahan pelajaran (Djamarah, 2000: 54). Sementara itu, Alat peraga jembatan garis bilangan adalah modifikasi dari konsep balok garis bilangan. Menurut Muhsetyo dkk, (2009: 317) Balok garis bilangan merupakan bentuk 
modifikasi dari tangga maupun pita garis bilangan dengan pertimbangan bahwa alat ini lebih memenuhi kriteria atau syarat dari pengadaan alat peraga. Prinsip kerja jembatan garis bilangan ini adalah mengikuti prinsip kerja garis bilangan.

Berdasarkan uraian masalah di atas, maka peneliti mencoba untuk melakukan penelitian yang berjudul "pengaruh metode demonstrasi dengan alat peraga jembatan garis bilangan terhadap hasil belajar matematika materi bilangan bulat" dengan tujuan untuk mengetahui bagaimana proses pembelajaran matematika materi bilangan bulat dengan metode demonstrasi menggunakan alat peraga jembatan garis bilangan, bagaimana hasil belajar matematika materi bilangan bulat setelah menggunakan metode demonstrasi dengan alat peraga jembatan garis bilangan, serta seberapa besar pengaruh penggunaan metode demonstrasi dengan alat peraga jembatan garis bilangan terhadap hasil belajar matematika materi bilangan bulat siswa kelas IV SDN 2 Belawa kabupaten Cirebon.

\section{METODE PENELITIAN}

Penelitian ini merupakan penelitian eksperimen dengan menggunakan desain OneGroup-Pretest-Posttest Design.

\section{$\mathrm{O}_{1} \mathrm{X} \mathrm{O}_{2}$}

Keterangan :

$\mathrm{X}=$ treatment yang diberikan

$\mathrm{O}_{1}=$ nilai pretest (sebelum diberi perlakuan)

$\mathrm{O}_{2}=$ nilai posttest (setelah diberi perlakuan) (Sugiyono, 2010: 110)

Teknik sampling yang digunakan dalam penelitian ini adalah dengan teknik purpose sampling. Pemilihan teknik purpose sampling ini dimaksudkan agar penelitian yang dilakukan sesuai dengan masalah yang sedang dihadapi di SDN 2 Belawa khususnya pada pembelajaran matematika materi bilangan bulat. Sampel dalam penelitian ini adalah siswa kelas IV yang berjumlah 36 siswa. Sementara populasi dalam penelitian ini adalah seluruh siswa SDN 2 Belawa Kabupaten Cirebon yang berjumlah 269 siswa. Sebelum siswa kelas IV diberikan perlakuan/ treathment menggunakan metode demonstarsi dengan alat peraga jembatan garis bilangan, para siswa diberikan pretes terlebih dahulu. Hal ini dimaksudkan agar peneliti mengetahui kemampuan awal siswa. Setelah diberikan pretest, baru kemudian para siswa kelas IV diberikan pembelajaran matematika materi bilangan bulat menggunakan metode demonstrasi dengan alat peraga jembatan garis bilangan. Dan setelah proses pembelajaran selesai, para siswa diberikan posttest. 
Teknik pengumpulan data dalam penelitian ini yaitu (1) Tes. Tes adalah suatu alat atau prosedur yang sistematis dan objektif untuk memperoleh data-data atau keteranganketerangan yang diinginkan tentang seseorang dengan cara yang boleh dikatakan tepat dan cepat (Arikunto, 2012: 46). Tes dalam penelitian ini berupa tes tertulis, baik pada saat prettest maupun posttest. Tes ini dilakukan untuk mengukur seberapa jauh pemahaman siswa terhadap materi operasi hitung bilangan bulat ketika sebelum dan sesudah pembelajaran. (2) Angket. Angket merupakan teknik pengumpulan data yang dilakukan dengan cara memberi seperangkat pertanyaan atau pernyataan tertulis dengan responden untuk dijawabnya (Sugiyono, 2015: 199). Angket ini digunakan untuk mengetahui seberapa jauh pemahaman siswa terhadap penggunaan alat peraga jembatan garis bilangan pada mata pelajaran matematika materi operasi hitung bilangan bulat. Bentuk instrumen ini menggunakan bentuk skala likert yang mana skala likert ini digunakan untuk jawaban yang bersifat jelas (Sangat Setuju, Setuju, Tidak Setuju, Sangat Tidak Setuju).

Sementara itu, teknik analisis data dalam penelitian ini, yang pertama yaitu teknik analisis data angket. Pengolahan data angket menggunakan rumus:

$P=X 100 \%$

Keterangan :

$\mathrm{P}=$ Prosentase

$\mathrm{X}=$ Jumlah Skor yang Diperoleh

$\mathrm{A}=$ Skor Maksimal

Dengan kriteria interprestasi sebagai berikut :

- Angka 0\% - 20\% = Sangat Lemah

- Angka 21\% - 40\% = Lemah

- Angka 41\% - $60 \%$ = Cukup

- Angka 61\% - 80\% = Kuat

- Angka 81\% - 100\% = Sangat Kuat (Riduwan 2010: 89)

Dan teknik analisis data yang kedua yaitu analisis uji regresi. Analisis uji regresi digunakan untuk memprediksi seberapa jauh perubahan nilai variabel dependen apabila nilai variabel independen dimanipulasi/dirubah-rubah atau dinaik-turunkan (Sugiyono, 2010: 260). Selain itu, metode ini juga dapat digunakan untuk menentukan bentuk hubungan antara kedua variabel sekaligus korelasi antara keduanya. 


\section{HASIL DAN PEMBAHASAN}

\section{A. Hasil Penelitian}

\section{Analisis Data Angket}

Berdasarkan hasil penelitian, berikut akan disajikan deskripsi data yang diperoleh dari hasil analisis instrumen angket respon siswa terhadap pembelajaran matematika menggunakan metode demonstrasi dengan alat peraga jembatan garis bilangan kepada 36 siswa kelas IV SDN 2 Belawa Kabupaten Cirebon.

Tabel 1. Rekapitulasi Angket Positif

\begin{tabular}{|c|c|c|c|c|c|c|c|c|c|c|}
\hline \multirow{2}{*}{ No } & \multicolumn{2}{|c|}{ STS } & \multicolumn{2}{|c|}{$\mathrm{TS}$} & \multicolumn{2}{|c|}{$S$} & \multicolumn{2}{|c|}{ SS } & \multicolumn{2}{|c|}{ JUMLAH } \\
\hline & $\mathrm{F}$ & $\mathrm{P}$ & $\mathrm{F}$ & $\mathrm{P}$ & $\mathrm{F}$ & $\mathrm{P}$ & $\mathrm{F}$ & $\mathrm{P}$ & $\mathrm{F}$ & $\mathrm{P}$ \\
\hline 1 & 0 & $0 \%$ & 0 & $0 \%$ & 2 & $6 \%$ & 34 & $94 \%$ & 36 & $100 \%$ \\
\hline 2 & 0 & $0 \%$ & 0 & $0 \%$ & 26 & $72 \%$ & 10 & $28 \%$ & 36 & $100 \%$ \\
\hline 3 & 3 & $8 \%$ & 2 & $6 \%$ & 14 & $39 \%$ & 17 & $47 \%$ & 36 & $100 \%$ \\
\hline 5 & 0 & $0 \%$ & 2 & $6 \%$ & 13 & $36 \%$ & 21 & $58 \%$ & 36 & $100 \%$ \\
\hline $6^{B}$ & 0 & $0 \%$ & 0 & $0 \%$ & 13 & $36 \%$ & 23 & $64 \%$ & 36 & $100 \%$ \\
\hline 7 & 1 & $3 \%$ & 2 & $6 \%$ & 15 & $42 \%$ & 18 & $50 \%$ & 36 & $100 \%$ \\
\hline 9 & 0 & $0 \%$ & 1 & $3 \%$ & 12 & $33 \%$ & 23 & $64 \%$ & 36 & $100 \%$ \\
\hline 10 & 0 & $0 \%$ & 1 & $3 \%$ & 12 & $33 \%$ & 23 & $64 \%$ & 36 & $100 \%$ \\
\hline 12 & 3 & $8 \%$ & 0 & $0 \%$ & 17 & $47 \%$ & 16 & $44 \%$ & 36 & $100 \%$ \\
\hline 13 & 0 & $0 \%$ & 3 & $8 \%$ & 15 & $42 \%$ & 18 & $50 \%$ & 36 & $100 \%$ \\
\hline 14 & 1 & $3 \%$ & 0 & $0 \%$ & 11 & $31 \%$ & 24 & $67 \%$ & 36 & $100 \%$ \\
\hline 18 & 4 & $11 \%$ & 5 & $14 \%$ & 17 & $47 \%$ & 10 & $28 \%$ & 36 & $100 \%$ \\
\hline 19 & 1 & $3 \%$ & 2 & $6 \%$ & 13 & $36 \%$ & 20 & $56 \%$ & 36 & $100 \%$ \\
\hline $20 \mathrm{~B}$ & 0 & $0 \%$ & 3 & $8 \%$ & 15 & $42 \%$ & 18 & $50 \%$ & 36 & $100 \%$ \\
\hline $\begin{array}{l}\text { Rata- } \\
\text { rata }\end{array}$ & 1 & $3 \%$ & 1 & $3 \%$ & 14 & $39 \%$ & 20 & $55 \%$ & 36 & $100 \%$ \\
\hline
\end{tabular}

Berdasarkan tabel 1 di atas, diperoleh bahwa siswa yang menyatakan sangat setuju dengan pembelajaran matematika menggunakan metode demonstrasi dengan alat peraga jembatan garis bilangan adalah sebesar 55\% atau sebanyak 20 siswa. 39\% atau sebanyak 14 siswa menyatakan setuju, 4\% atau sebanyak 1 siswa menyatakan tidak setuju dan yang menyatakan sangat tidak setuju hanya 3\% atau sebanyak 1 siswa. Sehingga dapat disimpulkan bahwa 94\% atau sebanyak 34 siswa merespon positif pembelajaran matematika menggunakan metode demonstrasi dengan alat peraga jembatan garis bilangan. 
Sementara itu, untuk melihat respon siswa terhadap pembelajaran matematika menggunakan metode demonstrasi dengan alat peraga jembatan garis bilangan berdasarkan angket negatif adalah sebagaimana tabel berikut:

Tabel 2. Rekapitulasi Angket Negatif

\begin{tabular}{ccccccccccc}
\hline \multirow{2}{*}{ No } & \multicolumn{2}{c}{$\mathrm{SS}$} & \multicolumn{2}{c}{$\mathrm{S}$} & \multicolumn{2}{c}{$\mathrm{TS}$} & \multicolumn{2}{c}{$\mathrm{STS}$} & \multicolumn{2}{c}{ Jumlah } \\
\cline { 2 - 10 } & $\mathrm{F}$ & $\mathrm{P}$ & $\mathrm{F}$ & $\mathrm{P}$ & $\mathrm{F}$ & $\mathrm{P}$ & $\mathrm{F}$ & $\mathrm{P}$ & $\mathrm{F}$ & $\mathrm{P}$ \\
\hline 4 & 3 & $8 \%$ & 4 & $11 \%$ & 14 & $39 \%$ & 15 & $42 \%$ & 36 & $100 \%$ \\
\hline 8 & 5 & $14 \%$ & 7 & $19 \%$ & 10 & $28 \%$ & 14 & $39 \%$ & 36 & $100 \%$ \\
\hline 11 & 5 & $14 \%$ & 3 & $8 \%$ & 5 & $14 \%$ & 23 & $64 \%$ & 36 & $100 \%$ \\
\hline 15 & 2 & $6 \%$ & 9 & $25 \%$ & 16 & $44 \%$ & 9 & $25 \%$ & 36 & $100 \%$ \\
\hline 16 & 6 & $17 \%$ & 8 & $22 \%$ & 5 & $14 \%$ & 17 & $47 \%$ & 36 & $100 \%$ \\
\hline 17 & 5 & $14 \%$ & 15 & $42 \%$ & 6 & $17 \%$ & 10 & $28 \%$ & 36 & $100 \%$ \\
\hline Rata-rata & 4 & $12 \%$ & 8 & $21 \%$ & 9 & $26 \%$ & 15 & $41 \%$ & 36 & $100 \%$ \\
\hline & & & & & & & & & \\
\hline
\end{tabular}

Tabel 2 di atas menunjukkan bahwa siswa yang menyatakan sangat setuju adalah sebesar $12 \%$ atau sebanyak 4 siswa. $21 \%$ atau sebanyak 8 siswa menyatakan setuju, 26\% atau sebanyak 9 siswa menyatakan tidak setuju dan yang menyatakan sangat tidak setuju adalah sebesar $41 \%$ atau sebanyak 15 siswa. Sehingga berdasarkan deskripsi angket negatif pada tabel 2 di atas dapat disimpulkan bahwa 67\% atau sebanyak 24 siswa merespon positif pembelajaran matematika menggunakan metode demonstrasi dengan alat peraga jembatan garis bilangan.

Dari data respon siswa yang diperoleh dari 36 siswa dengan jumlah item angket sebanyak 20, maka skor ideal untuk variabel metode demonstrasi dengan alat peraga jembatan garis bilangan tersebut adalah 20 item angket x 36 responden $x 4$ (skor tertinggi tiap item $)=2880$. Jumlah pencapaian skor hasil penyebaran angket adalah 2378. Maka presentase pencapaian skor respon siswa adalah:

2378

$x 100 \%=85 \%$

2880

Skor tersebut tergolong pada kategori sangat kuat yang berada di antara $81 \%-100 \%$

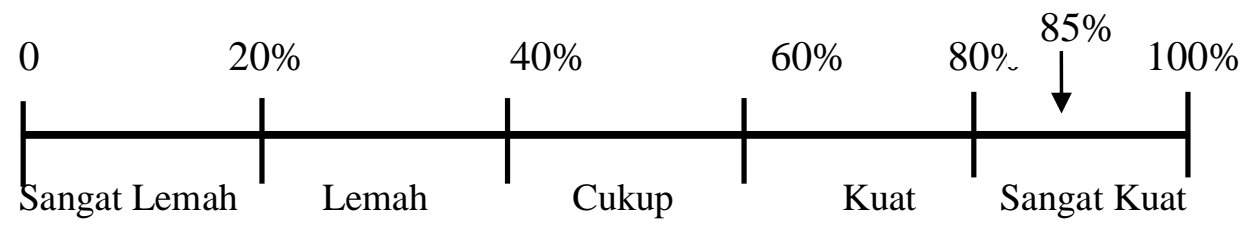




\section{Analisis Data Tes}

Adapun hasil belajar matematika materi bilangan bulat siswa kelas IV SDN 2 Belawa sebelum (pretest) dan sesudah (posttest) diberi perlakuan dengan menggunakan metode demonstrasi dengan alat peraga jembatan garis bilangan adalah sebagai berikut:

Tabel 3. Hasil Pretes

\begin{tabular}{ccccccccc}
\hline & N & Missing & Min & Max & Mode & Sum & Median & Mean \\
\hline $\begin{array}{c}\text { Hasil belajar } \\
\text { valid }\end{array}$ & 36 & 0 & 43.00 & 87.00 & 43.00 & 2002.00 & 53.00 & 55.61 \\
& 36 & 0 & & & & & & \\
\hline
\end{tabular}

Tabel 3 di atas menunjukkan bahwa jumlah siswa yang mengikuti pretest sebanyak 36 siswa, dengan nilai terendah sebesar 43 dan nilai tertinggi 87. Sementara itu mean atau rata-rata pretest sebesar 55,6.

Sementara itu, untuk hasil postest materi bilangan bulat kelas IV SDN 2 Belawa adalah sebagai berikut:

Tabel 4. Hasil Posttest

\begin{tabular}{ccccccccc}
\hline & $\mathrm{N}$ & Missing & Min & Max & Mode & Sum & Median & Mean \\
\hline $\begin{array}{c}\text { Hasil belajar } \\
\text { valid }\end{array}$ & 36 & 0 & 62.00 & 93.00 & 62.00 & 2614.00 & 68.0000 & 72.6111 \\
\hline
\end{tabular}

Tabel 4 di atas menunjukkan bahwa jumlah siswa yang mengikuti posttest sebanyak 36 siswa, dengan nilai terendah sebesar 62 dan nilai tertinggi 93. Sementara itu mean atau rata-rata pretest sebesar 72,6.

Untuk mengetahui seberapa besar peningkatan hasil belajar siswa kelas IV SDN 2 Belawa antara nilai prestest dan posttest dapat menggunakan uji N-Gain. Adapun hasil perhitungannya adalah sebagai berikut:

Tabel 5. Uji N-Gain

\begin{tabular}{clcccc}
\hline- & \multicolumn{1}{c}{ Nama } & Pretes & Postes & Gain & Kriteria \\
\hline 1 & Aisyah Juliani & 68 & 87 & 0,594 & Sedang \\
\hline 2 & Aenun Nurfadilah & 56 & 75 & 0,432 & Sedang \\
\hline 3 & Cindy Ayuningtias & 87 & 93 & 0,462 & Sedang \\
\hline 4 & Diki Nurrohman & 50 & 62 & 0,240 & Rendah \\
\hline 5 & Dilla Chindy Aulia & 50 & 62 & 0,240 & Rendah \\
\hline 6 & Desta Syahluna Moza & 50 & 68 & 0,360 & Sedang \\
\hline 7 & Dewi Anggraeni & 43 & 62 & 0,333 & Sedang \\
\hline
\end{tabular}




\begin{tabular}{clcccc}
\hline 8 & Fazri Nurhidayat & 62 & 68 & 0,158 & Rendah \\
\hline 9 & Gina Safira & 56 & 68 & 0,273 & Rendah \\
\hline 10 & Hendra Saputra & 43 & 62 & 0,333 & Sedang \\
\hline 11 & Isma Wardhana & 62 & 81 & 0,500 & Sedang \\
\hline 12 & Jehan Yunaidi & 62 & 81 & 0,500 & Sedang \\
\hline 13 & Kia Ramadani & 43 & 62 & 0,333 & Sedang \\
\hline 14 & Mia Rahmawati & 56 & 75 & 0,432 & Sedang \\
\hline 15 & Muhammad Agum Padria & 62 & 87 & 0,658 & Sedang \\
\hline 16 & Muhammad Alfajri & 87 & 93 & 0,462 & Sedang \\
\hline 17 & Muhammad Ilham & 43 & 62 & 0,333 & Sedang \\
\hline 18 & M. Izwar Ramadani & 87 & 93 & 0,462 & Sedang \\
\hline 19 & Mega Aulia & 43 & 68 & 0,439 & Sedang \\
\hline 20 & Naufal Taufiqurrohman & 50 & 62 & 0,240 & Rendah \\
\hline 21 & Nani Indriyani & 62 & 75 & 0,342 & Sedang \\
\hline 22 & Nina Meilinda & 62 & 75 & 0,342 & Sedang \\
\hline 23 & Nunu Nugraha & 43 & 68 & 0,439 & Sedang \\
\hline 24 & Novita Zahwa Anggraeni & 56 & 87 & 0,705 & Tinggi \\
\hline 25 & Putri Sasa Amelia & 43 & 62 & 0,333 & Sedang \\
\hline 26 & Rama aditya & 50 & 75 & 0,500 & Sedang \\
\hline 27 & Riska Amelia & 56 & 75 & 0,432 & Sedang \\
\hline 28 & Rizki Eka & 43 & 62 & 0,333 & Sedang \\
\hline 29 & Regina Pera & 43 & 68 & 0,439 & Sedang \\
\hline 30 & Reva Aulia & 43 & 62 & 0,333 & Sedang \\
\hline 31 & Santi Yuliana & 43 & 62 & 0,333 & Sedang \\
\hline 32 & Siti Sahidatunnisa & 43 & 62 & 0,333 & Sedang \\
\hline 33 & Sukma Riana & 62 & 87 & 0,658 & Sedang \\
\hline 34 & Taufik Ramadhan & 93 & 0,462 & Sedang \\
\hline 35 & Tedi Firmansyah & 56 & 68 & 0,273 & Rendah \\
\hline 36 & Tesa Sapiya & 52 & 0,240 & Rendah \\
\hline & $\quad$ JUMLAH & 2602 & 14,279 & \\
\hline & RATA-RATA & 72,61 & 0,40 & Sedang \\
\hline & & & & \\
\hline
\end{tabular}

Dari Tabel 5, terlihat jelas bahwa peningkatan hasil belajar siswa berdasarkan nilai pretest dan postest diperoleh rata-rata normalisasi gain sebesar 0,40 . Hal ini berarti bahwa hasil belajar siswa termasuk dalam kriteria sedang. Persentase normalized gain pada kriteria tinggi sebesar 2,7\% (1 siswa) dengan perolehan nilai normalized gain sebesar 0,705 . Pada kriteria sedang diperoleh persentase sebesar $78 \%$ (28 siswa) dengan perolehan nilai normalized gain terbesar 0,65 dan nilai terkecilnya 0,33. Sedangkan persentase normalized gain pada kriteria rendah diperoleh $19 \%$ (7 siswa) dengan perolehan normalized gain terbesar pada kriteria rendah sebesar 0,27 dan nilai normalized gain terkecil sebesar 0,15 . 


\section{Analisis Uji Hipotesis}

a. Uji Determinasi (R Square)

Tabel 6. Uji determinasi

\begin{tabular}{crrrr}
\hline Model & R & R Square & $\begin{array}{c}\text { Adjusted R } \\
\text { Square }\end{array}$ & Std. Error of the Estimate \\
\hline 1 & $.806^{\mathrm{a}}$ & .650 & .640 & 6.63421
\end{tabular}

a. Predictors: (Constant), penggunaan alat peraga jembatan garis bilangan

b. Dependent Variable: Hasil Belajar

Pada Tabel 6 di atas diketahui bahwa R Square sebesar 0,650 (kuadrat dari koefisien korelasi 0,806). R Square disebut koefisien determinan yang dalam hal ini $65 \%$. Dari nilai tersebut dapat diartikan bahwa penggunaan metode demonstrasi dengan alat peraga jembatan garis bilangan berpengaruh sebesar 65\% terhadap hasil belajar matematika materi bilangan bulat pada siswa kelas IV SDN 2 Belawa, sedangkan sisanya dipengaruhi oleh faktor lain.

b. Uji Koefisien Regresi

Tabel 8. Uji Koefisien Regresi

\begin{tabular}{|c|c|c|c|c|c|c|}
\hline & \multirow[t]{2}{*}{ Model } & \multicolumn{2}{|c|}{$\begin{array}{l}\text { Unstandardized } \\
\text { Coefficients }\end{array}$} & \multirow{2}{*}{$\begin{array}{c}\begin{array}{c}\text { Standardized } \\
\text { Coefficients }\end{array} \\
\text { Beta }\end{array}$} & \multirow[t]{2}{*}{$\mathrm{T}$} & \multirow[t]{2}{*}{ Sig. } \\
\hline & & $\mathrm{B}$ & Std. Error & & & \\
\hline \multirow{2}{*}{1} & (Constant) & -72.576 & 18.295 & & -3.967 & .000 \\
\hline & Variabel X & 2.198 & .276 & .806 & 7.951 & .000 \\
\hline
\end{tabular}

a. Dependent Variable: Hasil Belajar

$$
Y=a+b X
$$

Y adalah variabel dependent, dalam hal ini adalah Hasil belajar matematika materi bilangan bulat, dan $\mathrm{X}$ adalah variabel independent, dalam hal ini adalah Penggunaan metode demonstrasi dengan alat peraga jembatan garis bilangan. Sedangkan a dan b adalah nilai konstanta yang dicari.

Berdasarkan hasil regrasi diketahui nilai constant-nya adalah -72.576 dan nilai Hasil belajar adalah 2,198. Dari keterangan tersebut kita dapat memperoleh persamaan regresi berikut ini: sebagai berikut:

$\boldsymbol{Y}=-72.576+2,198 \boldsymbol{X}$

Nilai konstanta dari koefficien regresi sebesar -72.576 , hal ini menyatakan bahwa jika tidak ada kenaikan nilai atau skor dari variabel penggunaan metode 
demonstrasi dengan alat peraga jembatan garis bilangan, maka variabel penggunaan metode demonstrasi dengan alat peraga jembatan garis bilangan adalah -72.576. Koefficien regresi sebesar 2,198 menyatakan bahwa setiap terjadi penambahan skor variabel penggunaan metode demonstrasi dengan alat peraga jembatan garis bilangan akan dapat menambah kenaikan variabel Hasil belajar.

Setelah megetahui besarnya koefisien regresi, maka perlu dilakukan pengujian hipotesis untuk megetahui apakah terdapat pengaruh atau tidak. Uji hipotesis dapat dinyatakan dengan membandingkan nilai signifikan yaitu :

Jika nilai signifikan $>0,05$ dan $\mathrm{t}_{\text {hitung }}<\mathrm{t}_{\text {tabel }}$, maka $\mathrm{H}_{0}$ diterima

Jika nilai tidak signifikan $<0,05$ dan $\mathrm{t}_{\text {hitung }}<\mathrm{t}_{\text {tabel }}$, maka $\mathrm{H}_{0}$ ditolak

Jika $t_{\text {tabel }}$ dicari dengan $\alpha=0,05$ dan (df) n-k-1 atau 36-2-1 $=33$, jadi $t_{\text {tabel }}=2.03452$

Berdasarkan hasil uji regresi pada tabel 8 di atas menunjukkan bahwa nilai signifikansinya sebesar 0,000. Karena nilai signifikansinya lebih kecil dari 0,05 dan t hitung (7.951) lebih besar dari t tabel (2.03452) maka Ho ditolak, artinya bahwa penggunaan metode demonstrasi dengan alat peraga jembatan garis bilangan berpengaruh signifikan terhadap hasil belajar matematika materi bilangan bulat pada siswa kelas IV SDN 2 Belawa sebesar 65\%, sedangkan $35 \%$ dipengaruhi oleh faktor lain.

\section{B. Pembahasan}

\section{Respon siswa kelas IV SDN 2 Belawa terhadap penggunaan metode demonstrasi dengan alat peraga jembatan garis bilangan}

Berdasarkan hasil penelitian yang dilakukan di SDN 2 Belawa menunjukkan bahwa dari hasil penyebaran angket respon siswa sebanyak 20 pernyataan kepada 36 siswa kelas IV SDN 2 Belawa menunjukkan bahwa 94\% atau sebanyak 34 siswa merespon positif pembelajaran matematika menggunakan metode demonstrasi dengan alat peraga jembatan garis bilangan.

Dan berdasarkaan data yang diperoleh dari 36 siswa dengan jumlah item angket sebanyak 20, maka skor ideal untuk variable metode demonstrasi dengan alat peraga jembatan garis bilangan tersebut adalah 20 item x 36 siswa x 4 (skor tertinggi tiap item $)=2880$. Jumlah pencapaian skor hasil penyebaran angket adalah 2378. Maka presentase pencapaian skor respon siswa adalah:

2378

$\mathrm{x} 100 \%=85 \%$

2880 
Skor tersebut tergolong pada kategori sangat kuat yang berada di antara $81 \%-100 \%$.

Hal ini berarti bahwa proses transfer of knowledge tersebut tentunya akan lebih mudah dengan menggunakan media/alat peraga pembelajaran, karena dengan perantara media, hal abstrak akan lebih konkret dan mudah dimengerti oleh siswa. Berdasarkan teori piaget menyatakan bahwa anak usia 7 s/d 11 tahun berada pada tahap operasional konkret, yakni anak dapat memahami operasi (logis) dengan benda-benda konkret. Pada tahap ini, proses pemikiran anak mengarah pada kejadian nyata yang dapat diamati, anak belum mampu melakukan problem yang bersifat abstrak (Russefendi, 2006: 35).

\section{Hasil belajar siswa kelas IV SDN 2 Belawa pada materi bilangan bulat dengan} menggunakan metode demonstrasi dengan alat peraga jembatan garis bilangan

Berdasarkan permasalahan yang peneliti temukan bahwa penggunaan alat peraga pembelajaran di SDN 2 Belawa masih rendah, sehingga pembelajaran terkesan masih konvensional. Hasil belajar siswa dipengaruhi oleh berbagai faktor penunjang keberhasilan pembelajaran, diantaranya yaitu alat peraga yang digunakan guru selama proses pembelajaran berlangsung. Begitupun dengan hasil belajar siswa pada mata pelajaran Matematika di kelas IV SDN 2 Belawa yang mana peneliti menggunakan alat peraga jembatan garis bilangan.

Hasil penelitian menunjukkan bahwa dari 36 siswa yang mengikuti pretest diperoleh nilai terendah sebesar 43 dan nilai tertinggi 87. Sementara itu mean atau ratarata nilai pretest sebesar 55,6. Sementara itu, untuk nilai postest materi bilangan bulat kelas IV SDN 2 Belawa menunjukkan bahwa nilai terendah sebesar 62 dan nilai tertinggi 93. Sedangkan mean atau rata-rata postest sebesar 72,6. Hal ini berarti terjadi peningkatan antara nilai prestest dan postest sebesar 0,40 atau berada pada kategori sedang. Kenaikan hasil belajar tersebut tentu karena penggunaan metode demontrasi dengan alat peraga jembatan garis bilangan dapat mempermudah siswa dalam memahami materi bilangan bulat.

\section{Pengaruh penggunaan metode demonstrasi degnan alat peraga jembatan garis} bilangan terhadap hasil belajar matematika materi bilangan bulat

Setelah megetahui besarnya koefisien regresi, maka perlu dilakukan pengujian hipotesis untuk mengetahui apakah terdapat pengaruh atau tidak. Uji hipotesis dapat dinyatakan dengan membandingkan nilai signifikan yaitu :

Jika nilai signifikan $>0,05$ dan $t_{\text {hitung }}<\mathrm{t}_{\text {tabel }}$, maka $\mathrm{H}_{0}$ diterima

Jika nilai tidak signifikan $<0,05$ dan $\mathrm{t}_{\text {hitung }}<\mathrm{t}_{\text {tabel }}$, maka $\mathrm{H}_{0}$ ditolak 
Jika $t_{\text {tabel }}$ dicari dengan $\alpha=0,05$ dan (df) $n-k-1$ atau 36-2-1 $=33$, jadi $\mathrm{t}_{\text {tabel }}=2.03452$

Berdasarkan hasil uji regresi di atas nilai signifikansinya sebesar 0,000. Karena nilai signifikansi lebih kecil dari 0,05 dan t hitung (7.951) lebih besar dari t tabel (2.03452) maka Ho ditolak, artinya bahwa penggunaan alat peraga jembatan garis bilangan berpengaruh signifikan terhadap hasil belajar matematika materi bilangan bulat pada siswa kelas IV SDN 2 Belawa sebesar 65\%, sedangkan 35\% dipengaruhi oleh faktor lain.

Hal tersebut sejalan dengan pendapatnya Soejadi dalam Muhsetyo (2008: 1,2), bahwa matematika pada dasarnya memiliki objek dasar yang abstrak. kebastrakan matematika karena objek dasarnya abstrak yaitu fakta, konsep, operasi dan prinsip. Oleh karenanya dengan adanya alat peraga mampu menurunkan tingkat keabstrakan matematika tersebut. Hasil penelitian ini juga sejalan dengan beberapa penelitian yang telah dilakukan sebelumnya seperti yang dilakukan oleh Abdul Hadi (2011) yang berjudul “ Pengaruh Penggunaan Alat Peraga Kartu Kotif (Koin Positif Negatif) terhadap Hasil Belajar Matematika Siswa di MI Syamsul Huda Ciganjur Jakarta”. Kesimpulan yang didapatkan yaitu hasil penelitian mengenai pengaruh penggunaan alat peraga kartu kotif terhadap hasil belajar matematika siswa terdapat pengaruh penggunaan alat peraga kartu kotif terhadap hasil belajar matematika siswa pada materi operasi hitung bilangan bulat.

\section{SIMPULAN}

1. Respon siswa terhadap penggunaan metode demonstrasi dengan alat peraga jembatan garis bilangan pada materi bilangan bulat siswa kelas IV SD N 2 Belawa menunjukkan respon positif yang kuat, yakni sebesar $85 \%$

2. Hasil belajar siswa kelas IV SDN 2 Belawa pada materi bilangan bulat terjadi peningkatan antara nilai pretest dan posttest, yakni sebesar 0,40 atau berada pada kategori sedang.

3. Penggunaan metode demonstrasi dengan alat peraga jembatan garis bilangan berpengaruh terhadap hasil belajar siswa kelas IV SDN 2 Belawa. Besarnya pengaruh berdasarkan uji determinasi adalah sebesar $65 \%$. 


\section{DAFTAR PUSTAKA}

Arifuddin, A. (2016). Pembelajaran Matematika Model Quantum Teaching dengan Pendekatan Realistik untuk Meningkatkan Kemampuan Pemahaman Konsep Peserta Didik. Al Ibtida: Jurnal Pendidikan Guru MI, 3(2), 186-196

Arikunto. (2012). Dasar-dasar Evaluasi Pendidikan . Jakarta: Rineka Cipta.

Arsyad, A. (2013). Media Pembelajaran. Jakarta: Raja Grafindo persada.

Djamarah , S.B. (2000). Strategi Belajar Mengajar. Jakarta: Penerbit Rineka Cipta

Hadi, A. (2011). Pengaruh Penggunaan Alat Peraga Kartu Kotif (Koin Positif Negatif) terhadap Hasil Belajar Matematika Siswa di MI Syamsul Huda Ciganjur Jakarta. Skripsi: Jakarta

Maufur, S. (2016). Pengaruh Penggunaan Media Gambar Sketsa Terhadap Hasil Belajar Menulis Karangan Deskripsi Siswa Kelas V MIN Kota Cirebon. Al Ibtida: Jurnal Pendidikan Guru MI, 3(2), 241-252

Muhsetyo, G., ddk. (2009). Pembelajaran Matematika SD. Jakarta: Universitas Terbuka

Riduwan. (2010). Dasar-dasar statistika. Bandung : Alfabeta .

Russefendi. (2006). Dasar-dasar Matematika Modern. Bandung: Tarsito.

Sugiyono. (2010). Metodologi Penelitian Pendidikan. Bandung: Alfabeta.

Sugiyono. (2015). Metode Penelitian Pendidikan . Bandung : Alfabeta. 